\title{
Concepts of Learner-Centred Teaching
}

\section{OPEN ACCESS}

Manuscript ID:

EDU-2020-08032926

Volume: 8

Issue: 3

Month: June

Year: 2020

P-ISSN: 2320-2653

E-ISSN: 2582-1334

Received: 18.04.2020

Accepted: 15.05.2020

Published: 01.06.2020

Citation:

Shah, Rajendra Kumar.

"Concepts of Learner-

Centred Teaching." Shanlax

International Journal of

Education, vol. 8, no. 3, 2020, pp. 45-60.

DOI:

https://doi.org/10.34293/

education.v8i3.2926

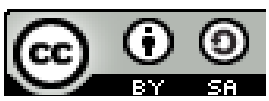

This work is licensed under a Creative Commons Attribution-ShareAlike 4.0 International License

\author{
Rajendra Kumar Shah \\ Associate Professor, Tribhuvan University (Sanothimi Campus), Bhaktapur, Nepal \\ https://orcid.org/0000-0003-0533-1338
}

\begin{abstract}
This article traces the historical development of learner-centered teaching (LCT) and examines the major contributions of educators. Accordingly, this article has also analyzed the perception of various educationists regarding LCT. LCT is an approach to teaching that is increasingly being encouraged in education. The paradigm shifts away from teaching to importance on learning have boosted the power to be moved from the teacher to the student. The teacher focused/transmission of information formats, such as lecturing, have begun to be increasingly criticized, and this has paved the way for the widespread growth of LCT as an alternative approach. Many terms have been linked with LCT, such as flexible learning, experiential learning, self-directed learning, and therefore the slightly overused term LCT can mean different things to different people. Also, in practice, it is described by a range of terms, and this has led to confusion surrounding its implementation. LCT has a long history of development. Two of the first educators to emphasize the learners were Confucius and Socrates (5th to 4th centuries B.C.). Over two millennia passed before seventeenth-century Englishman Locke introduced experiential education (the idea that one learns for experience). Another two hundred years spent before European educators Pestalozzi, Herbart, and Froebel designed and popularized experience-based, learner-centered curricula. In the school system, the concept of LCT has been derived, in particular, from the work of Froebel and the idea that the professor should not interfere with this process of maturation, but act as a guide. A century later, nineteenth-century educator Colonel Francis Parker brought this method to America. Twentieth-century Russian sociologist Lev Vygotsky, Swiss psychologist Jean Piaget, American philosopher and educator Dewey shaped the existing LCT into a program called constructivism. Keywords: Learner-Centered Teaching (LCT), Teacher-Centered Teaching (TCT), Pedagogy, Teaching, Learning, Children, Learner.
\end{abstract}

\section{Concepts of Learner-Centred Teaching}

The traditional teaching, which is distinguished by its expository form and narrative character, has been the most pervasive pedagogical model around the world. Critique to this model has been developed at different historical moments, and socio-economic and geographical contexts, with different political aims in mind, by various actors such as critical pedagogues from developing countries (e.g., Freire), educationalists in the western world (e.g., Rousseau, Dewey, and Vygotsky) and international organizations involved in education (e.g., UNESCO and UNICEF). Traditional teaching has been criticized for relegating education to an act of depositing whereby teachers make deposits and students receive, memorize, and repeat to the best of their efforts and capacities (Freire 1996). Such practices have also been examined for being ineffective and leading to the acquisition of skills of a lower taxonomic level (Gauthier and Dembele 2004), for undermining spontaneity and initiative among students (O'Sullivan 2004) and for inhibiting creativity and critical thinking (Freire 1996). Early progressive movements proposing alternatives to traditional teaching originated in the second half of the 1800s (Windschitl 2002). In the following period, several other dilemmas have been proposed, yet the current discussion is managed by two competing approaches. These are traditional teaching approaches and learner-centered teaching (LCT), constructivism. The former advocate's structure and some directivity in supporting the learning process effectively in school environments, and the second is contrasted with the traditional model (Gauthier and Dembele 2004). 
The LCT has been known by a variety of terms, including child-centered education; child-centered pedagogy; child-centered teaching; child-centered learning, learner-centered approach, studentcentered teaching, student-centered learning; learnercentredness; or student-centered. These terms have all been used interchangeably (Harmelen, 1998; Lall, 2010; O'Neill \& McMahon, 2005). Chung and Walsh (2000) state that there have been more than 40 different meanings of the term in contemporary usage. Because these concepts are applied across all spectrums/levels of education, 'learner-centered teaching' and 'student-centered teaching' tend to be the preferred terms for older learners, whereas 'child-centered' might be used in early-childhood or primary school contexts. More people are talking about learner-centered teaching (LCT) instead of child-centered teaching (CCT). This is because the term LCT covers a wider range of learners. So far as LCT is concerned, it has been identified that education needs to go beyond a concern with only children but a concern for a wider range of learners. Thus, the term LCT began to be used with more frequency in general education and is considered a more appropriate term to be applied to everyone in this learning society (Lambert and McCombs, 1997). The contemporary meanings of LCT draw from a wide range of disciplines and research bases, incorporating the historical meanings while accommodating the changing social, cultural, and educational needs of the present day, leading to a holistic understanding and interpretation of LCT.

$O$ 'Neil and McMahon (2005), in their discussion of the term LCT, link the concept with other terms such as flexible learning, experiential learning, and self-directed learning. They also emphasize that the term has been overused and can mean different things to different people. Similarly, Tabulawa (2003) states that 'learner-centredness' has "often been used interchangeably with 'participatory,' 'democratic,' 'inquiry-based,' and 'discovery' method, and so on. These strands differ from each other only in so far as they emphasize different degrees of learner autonomy" (p.9). According to Attard, Iorio, Geven, and Santa (2010), there is not a universally agreed definition about LCT, even though the term is being used by a range of informing policy-makers. In the same vein, Lea, Stephenson, and Troy (2003) state that there may be a variety of potential definitions of what LCT is and that different dimensions of the learning and teaching process are highlighted by various researchers and practitioners. According to Muzumara (2011), LCT includes practical activities such as panel discussions, quizzes, projects, brainstorming activities, role plays, debates, textbook study, field trips, and discovery learning. Learnercentered methods also include active learning in which learners solve problems, formulate questions of their own choice, and answer questions. Felder and Brent (2003) state that LCT has repeatedly been shown to be superior to the traditional teachercentered teaching (TCT) of instruction. However, LCT is not expected to diminish the importance of the instructional side of classroom activity, but instead, instruction is broadened to include other activities that produce excellent learners' outcomes.

Dupin-Bryant (2004) defines LCTas as a style of instruction that is responsive, collaborative, problemcenter,d, and democratic in which both learners and the instructor decide how and when learning occurs. On the other hand, LCT is considered as a style of instruction that is formally controlled and autocratic in which the professor directs how something and when learners learn. TCT is often associated with "transmission" models of teaching (lecture methods), which includes drill and practice. Typical characteristics of TCT include more teacher talk and questions than student talk and reliance on textbooks. Therefore, LCT puts pupils first in contrast to TCT. LCT is focused on the learners' needs, abilities, interests, and learning styles with the teacher as a facilitator of learning (Weimer, 2002). LCT is an approach to education focusing on the needs of the learners rather than others involved in the instructional process, such as teachers and administrators like headteachers and deputy headteachers. LCT departs from the traditional teaching methods (lecture methods) by focusing on learners more than teachers and learning more than teaching. Traditionally, educators direct the learning process, and students understand a receptive role in their education. With the approach of progressive education in the 21 st century and the influence of psychologists, some educators have largely displaced 
traditional teaching methods, which focused on how teachers taught instead of how learners learned.

\section{(Blumberg, 2008)}

Although learner-centered teaching (LCT) has recently become one of the most prevalent educational ideas in most of the country in the world, it has a long historical development. The history of LCT can be traced back more than 2000 years. According to Ozmon and Craver (1999), signs of LCT began appearing with the dawning of formal education. They can be followed back to the Sumerians and the development of written language (around 3500 B.C.). Within five hundred years, the Chinese had also established formal schools where early teachers emphasized individual character and citizenship. Perhaps the earliest unusual teachers to have a profound, direct effect on LCT was the Chinese savant Confucius (551 B.C.-479 B.C.). Ozmon \& Craver (1999:105) cited in Henson (2003) argue that Confucius stressed character and citizenship, while Socrates stressed the individual. They believed that every person must strive for the continual development of self until excellence is produced. Confucius stressed character and good citizenship. He believed that every person should strive for the steady development of self until excellence is achieved.

In the West, notions of LCTcan be seen to reach back as early as Plato's Socratic dialogues (Entwistle, 1970: 11; Brodie, Lelliott, and Davis, 2002: 542). In these dialogues, LCT manifests itself in the strategic questioning through which the teacher draws out the ideas of the student based on his current knowledge and understanding, and Socrates stressed the individual. Socrates, in the form of dialogues, illustrated an early concern with 'scaffolding,' believing that a person's latent knowledge needed the guidance of an 'other' who is more knowledgeable to bring it out. Therefore, all that a teacher can do is to help a learner to become aware of his current knowledge, his mistakes, and his limitations. And it is only the student who can bring about the improvement (Perkinson, 1980). The concept was incorporated in the strategic questioning of Plato (Brodiea, Lelliotta, \& Davis, 2002; Entwistle, 2012; Mtika\& Gates, 2010).

The earliest known regular teaching method was the tutorial organization. For five thousand years, the tutorial method continued to dominate. Although Locke recommended its use, he introduced the concept of tabula rasa (blank slate), intending that at birth, the mind is a blank slate, and the only way to fill it is by having adventures, feeling these experiences, and reflecting on them Henson (2003). Locke's experience-based educational philosophy gave birth to a concept called experiential education (Garforth, 1964). Locke believed that the mind gets its understanding from experience. Stimulated by Locke's philosophical assertion, philosophers like Rousseau and other philosophers who were inspired by Rousseau and continued to inspire others explored the breadth and depth of the LCT to teaching and learning. The details of their explorations are going to be explained below.

The Swiss-born philosopher Jean Jacques Rousseau (1712-1778) was one of history's most famous contributors to LCT. Though such notions of LCT have existed for a long time, there was little concern with specially treating children until Rousseau's 'Emile' was published in 1762, which became the first comprehensive presentation of LCT (Entwistle, 1970; Darling, 1994, Tabulawa, 2003). In Emile, Rousseau declared that 'nature provides for the child's growth in her fashion, and this should never be thwarted' (p. 187). In this way, Rousseau introduced to educational thought a completely new emphasis, presenting ideas that were LCT, such as arguing that children are naturally active, both physically and mentally; and that LCT requires a focus on individual differences and levels of learning (Entwistle, 2012; Mtika \& Gates, 2010). Emile, caught many people's interest, arguing for an approach to education that was LCT and experienced-based (Henson, 2003). Emile sought to replace the conventional and formal education of the day with training that should be natural and spontaneous. Learning in this era, however, was limited to the education of boys and did not promote the equal treatment of girls (Lall, 2010).

The fundamental principle that runs throughout 'Emile' is that children have their ' ways of seeing, thinking and feeling,' and we should not try to teach them in a way we as adults see, think and feel (Rousseau, 1762: 54). Children are interested in 
finding things out for themselves, so education should allow children opportunities to discover things and draw conclusions from their own experiences. They should not be made to learn things that are beyond their grasp (Darling, 1994). Rousseau criticizes conventional education as a failure in directing children's attention to matters utterly remote from their minds, providing no opportunities for children to the reason for themselves, and putting children in an environment where they can be neither happy nor free (Rousseau, 1762). He states, it matters little what he learns; it does matter that he should do nothing against his will' (p. 135). With such an understanding, education is not a matter of teaching knowledge but developing children's interests and ways of learning with their desire to learn. For Rousseau, this is the basic principle for any good education. In his words, the school should be made to fit the child rather than the other way round, and the curriculum should be managed by children's interests and needs (ibid).

Furthermore, Rousseau recognizes the fact that individual children vary; therefore, education needs to be individualized to meet their individual needs and level of development (Darling, 1994). He argued that children should be given more real liberty and let them do more for themselves. He viewed that in the learning, experience plays a vital role, and it precedes instruction. He stated that man is formed by education and further elaborated:

We are born weak; we need power; helpless, we need aid; foolish, we require a reason. All that we need at birth, all that we need when we come to man's property, is the legacy of learning.

This knowledge comes to us from nature, from individuals or things. The inner growth of our media and faculties is the study of nature, the use we learn to make of this extension is the direction of men, what we gain by our knowledge of our surroundings is the education of things.

Thus we are guided by three masters. If their instruction conflicts, the scholar is ill-educated and will never be at quiet with himself; if their teaching agrees, he goes accurate to his goal; he lives at an agreement with himself; he is wellintelligent.
Now of these three parts in education, nature is wholly beyond our control; things are only partly in our power; the education of men is the only one controlled by us, and even here, our power is largely illusory... (p. 6).

Rousseau further cautioned us to be careful that education of man, which is the one controlled by us, can be ruined 'with our foolish and pedantic methods we are always preventing children from learning what they could learn much better by themselves, while we neglect what we alone can teach them. Rousseau's point of view is not, to begin with, a vast amount of information that we want children to acquire, but begin with what the child is capable of learning and interested. Also, he arg, used that children have their ways of seeing and understanding, which are different from the adults. Children can exercise reason on what is within their own experience and not what is beyond it (Doddington and Hilton, 2007). Therefore instead of beginning from the outside, such as from subjects and specific skills thought to be important from the adult points of view, we should begin from what is already in the child's experience and capacity to develop. In this way, learning will be joyful, and it will lead to the development of a person who is keen to continue to learn and ultimately grow as a responsible member of society (Sutherland, 1988).

According to Entwistle (1970), it was with Rousseau that there entered into education a completely new way of thinking. This new thinking of education, based on children's interests, their natural stages of development with an emphasis on first-hand experience and individual differences, was taken forward by later writers such as Pestalozzi (1746-1827) and Froebel (1782-1852) among others. Pestalozzi, Froebel, and John Dewey extended this approach to thinking about children and their education, developing and revising existing ideas, and ensuring that the application of these new approaches to education was sound (Darling, 1994). Other child-centered authorities have adopted, modified, or extended the principles put forth by Rousseau.

Pestalozzi (1746-1827) transferred some of the central themes in Rousseau's account of learning and teaching into his educational writing (Darling, 
1994). Pestalozzi believed that the whole child should be trained (physically, psychologically, and emotionally) and that children should be supported like a plant while they learn by doing. Children, according to Pestalozzi, should learn through activities, and they should be free to pursue their interests and draw their conclusions. They should not be anxious or put under stress, and their development should not be forced (Darling, 1994). Teachers, according to Pestalozzi, must respect children and base their discipline on love - the school should be like a good home, and the master should be like a good parent (Darling, 1994; Henson, 2003).

Pestalozzi continued to stress that education should be for the child, not the child for education, and he strongly criticized the education of his time for expecting too much of the child and forcing the child to learn miserably without attending to individual needs (Heafford, 1967). Pestalozzi stresses that education should take full account of what the child is capable of achieving mentally, physically, and intellectually. He claims that 'all instruction of man is then only the Arty of helping Nature to develop in her way; and this Art rests essentially on the relation and harmony between the impressions received by the child and the exact degree of his developed powers' (Pestalozzi, 1898: 57). In other words, 'to instruct men is nothing more than to help human nature to develop in its way, and the art of instruction depends primarily on harmonizing our message and the requirements we make upon the child with his powers at the moment' (Green, 1912: 87, cf. Darling, 1994: 18). The child should learn through activity and things. He should be free to pursue his interests and draw his conclusions. He should not be made anxious under stress, and his development should not be forced (Green, 1914; Darling, 1994). While advocating the need for the child to proceed at his own pace and recognizing the fact that the ability of children could vary considerably, Pestalozzi valued the instructional role of the teacher and was in favor of firm discipline in the classroom and believed in the value of hard work (Heafford, 1967).

Different from Rousseau, who presented his ideas of education in a novel focusing on an individual child cut off from society, Pestalozzi recognized the importance of education to all and realized that education is the key to the improvement of social conditions (Green, 1914; Heafford, 1967; Darling, 1994). He also gave some thought to how such educational ideas can be put into practice for broader implementation by stressing that there should be a sequence in the instruction given to children 'so that beginning and progress should keep pace with the beginning and progress of the powers to be developed in the child' (Pestalozzi, 1898: 58). He also valued the use of picture books and real objects to create visual experiences for learning and proposed the use of textbooks for teaching and learning as he recognized that few teachers were experts, and some teachers were ignorant. He believed that welldesigned textbooks could help solve the problems.

In Switzerland, Pestalozzi opened a school with a learner-centered curriculum. Pestalozzi thought that the whole child should be educated physically, mentally, and emotionally and that children should be provided like a plant while they learned by doing. Pestalozzi believed that teachers must respect children and base their discipline on love. He pointed out that the school should be like a good home, and the teacher should be like a good parent. Pestalozzi held the philosophical view of the child's innate wisdom. He argued that it must be nurtured as consciousness in the child unfolds. First comes moral education, and then comes intellectual education slowly merged into it. Intellectual education must start first centered on the perception of objects and then adapted and expanded as the mind of the child expands. His pedagogical idea envisioned children as active learners and emphasized to move away from rote learning and instruction practiced at that time. Pestalozzi indicated that the task of educators was not to instruct but to stimulate the self-activity of the children through the training of the senses (Doddington and Hilton, 2007). The ideals developed towards child centeredness promoted self-activity, freedom of movement, space, a garden, communal play, and work, etc. The traditional academic and syllabus centered approach was suggested to be replaced by a more LCT. In this regard, the curriculum is thought in terms of activity and participation rather than of knowledge to be obtained and facts to be stored. 
The first person who explicitly used the term 'child-centered' was said to be Froebel. The term 'child-centered' appeared in Froebel's 1826 book 'The Education of Man' (1885) and steadily gained greater prominence in the educational literature from the late 1800s (Chung \& Walsh, 2000). Froebel pioneered his child-centered ideas in kindergartens, thus developing his philosophy of education, which combines child-centered theory and method. Froebel confirmed that 'only by the extension and enrichment of the child's instinct to involve itself in active play could sympathetic adult educators help the child in his or her full development as acting, feeling, and thinking human being'(p. 14). Using these methods, kindergartens provided a child-centered curriculum, focusing on play and experimentation, gardening, and singing. Froebel's work promoted the idea that LCT implied that the teacher should not "conflict with this method of maturation, but act as a guide' (Simon, 1999). Simon highlighted that this was associated with the process of development or 'readiness,' i.e., the child will learn when he/she is ready.

Inspired by Rousseau as well as Pestalozzi, Froebel earnestly devoted himself to this 'new education' (Lawrence, 1952: 21). He believed that schooling should fit children's natural stages of development (Lilly, 1967; Darling, 1994; Chung and Walsh, 2000). Because young children think and learn differently from older children and adults, 'schooling for young children must differ from that for older children and adults' (Chung and Welsh, 2000: 217). Furthermore, Froebel stresses that 'every human being, even as a child, must be recognized, acknowledged, and fostered as a significant and essential member of humanity' (Froebel, 1886; Lawrence, 1952: 21). He stated that children should be regarded and cared for like plants: 'Given the right conditions, they would grow and unfold' (Lawrence, 1952: 195). The role of the teacher, consequently, is to provide the right conditions for children's growth. In other words, creating a positive learning environment was seen as an important factor for children to learn. Moreover, he sees children's play as a form of creative activity, and such creative work can be a means of knowledge (Darling, 1994). Froebel states:
Play, therefore, must not be left to chance. Just because he learns through play, a child learns willingly and learns much. So play, like learning and activity, had a definite period, and it must not be left out of the elementary curriculum. The educator must not only guide the play since it is so important, but he must also often teach this sort of play in the first instance. (Lilley, 1967: 167)

With his concern about the crucial function of play, Froebel began to devise some concrete techniques such as simple toys to be used as teaching equipment to translate his principles into practice. Froebel's elaboration on LCT had a strong impact on education in Europe as well as in America in the late 19thand early 20thcentury with lectures and exhibitions organized and the Froebel Society formed (Lawrence, 1952; Darling, 1994).

Froebel used the learner-centered, child-centered, experience-based ideas to expand the world's first kindergarten, a school for young children (Campbell, 1967). Pestalozzi's work, which was founded on the conception of education as development based on the nature of the child, advocated such ideas as nature walks, and the use of games and songs was much appreciated by Friedrich Froebel. As a result, Froebel used the philosophies of learner-centered, child-centered, and experience-based learning to develop the world's first kindergarten - a school for young children (Henson, 2003). Froebel viewed play as something important to the development of the child's awareness, with an emphasis that play is not only a form of creative activity but also the means through which a child grows increasingly aware of the world and his place in it (Froebel, 1885). Froebel's view is consistent with Rousseau's, namely that the best learning occurs when learners are manipulating objects and solving problems.

Froebel (1931) developed teaching methods that recognized play as one of the child's main ways of learning that the move away from TCT to LCT began to develop significantly. Froebel emphasized children's play in his kindergartens so that children naturally learn to understand the world. He suggested that children can be encouraged to understand physical objects and their properties in a natural way by providing them suitable toys and 
games (Sutherland, 1988). He realized that much of children's play activity is culturally based. Children naturally mimic, sing, dance, and listen to the stories from the world around them. He stated that these activities should be encompassed in teachinglearning activities (Doddington and Hilton, 2007). With his concern about the crucial function of play, Froebel began to devise some concrete techniques such as simple toys to be used as teaching equipment to translate his principles into practice. Froebel's elaboration on child-centered education had a strong impact on education in Europe as well as in America in the late $19^{\prime} \mathrm{h}$ and early 20 th century with lectures and exhibitions organized and the Froebel Society formed (Lawrence, 1952; Darling, 1994).

In the nineteenth century in Britain, the ideas of Froebelianism gradually spread and were no longer confined to the kindergarten but challenged the methods of teaching children in elementary (primary) schools. LCT was promoted in North America and the UK in the late 19th and early 20th centuries by continental philosophers, who questioned the nature of childhood and how children should be educated (Schweisfurth, 2013). However, there still existed in parallel with another educational ideology where schools continued to emphasize rote learning and authoritarian methods.

Richard Lovell Edgeworth developed the 'Practical Education' methodology course based on child-centered principles. This methodology emphasizes early childhood priorities such as playing with toys, performing simple tasks, and instilling obedience and truthfulness. Edgeworth explained particular ways in which children can be encouraged to learn through invention rather than being made to learn by rote, which is usually enforced discipline or instructed in facts beyond their comprehension (Doddington and Hilton, 2007). It provided a comprehensive theory of education that combines the ideas of Locke and Rousseau, as well as other educational writers. It was the first educational work to place more emphasis on experimental and holistic teaching methods, emphasizing the notion that children should be encouraged to discover for themselves and that 'children's attention, interest, and understanding should be awakened by sympathy'(Doddington\& Hilton, 2007, p. 7).
As we can see from the above analysis, the central tenets of learner-centered views lie in the respect for children's natural interests, their natural developmental stages, learning through experience and discovery, the recognition of the function of play in learning, and individual differences of each child. These ideas were returned, reformulated, as well as further developed by later writers such as Parker, Dewey, Piaget, Vygotsky, Bruner, Donaldson, and many others in the 20th century.

Henson (2003) asserts that American educators became serious about the LCT at the end of the civil war when a soldier and teacher named Colonel Francis Parker returned to his home state of New Hampshire, wherein 1865, he accepted principal ship in Manchester. Three years later, in 1868, unhappy with the rote memorization that characterized schools at that time, Parker accepted principal ship in Dayton, Ohio, where he headed the first normal school, giving demonstration lessons to help teachers learn how to use the child-centered teaching methods. Frustrated by the American's slow embracing of the child-centered approach, Parker went to Europe in Berlin to pursue an academic degree, because he got information that Europe was far ahead of America in the implementation of the child-centered education. His main goal was to learn immediately from the Europeans about their learner-centered education.

Campbell (1967:99) attests that on his return to the US in (1875) Parker accepted the Superintendence situation in Quincy, Massachusetts, where he gave model learner-centered lessons in all seven Quincy schools. He also held district-wide teachers' meetings, where he demonstrated learner-centered techniques to teachers. By replacing drill with inquiry activities, Parker restored the memorization of facts with understanding. It has to be stated, though, that some of the sections of the American society criticized Parker's new approach to reform the deplorable American education system. Such criticism, however, instead of having a negative impact, managed to have a positive impact by making Parker's LCT approach to education more popular in American schools. In the time of his death in 1902, Parker's LCTto education was adopted by many schools and had a lot of followers in the US. Seemingly this was the beginning of the new 
revolution in learning not only within the boundaries of the USA but beyond to other territories of the world because in the 21st century, according to Henson (2003), many countries are dropping rote learning and embracing the LCT approach to learning. Sparrow's (2000) attests that the only concern about the LCT approach is whether countries are implementing it correctly because the correctness of the implementation of the LCT approach is of great interest to many education systems of the world.

By 1940, the ideals of progressive education under the influence of Dewey became prevalent in the rhetoric of American education (Ravitch, 1983, Alexander, 2000), which focused on identifying the needs of the individual child and constructing educational contexts which supported individual interests by identifying children's differences with a curriculum designed to meet the natural order of the development of the child (Vadeboncoeur, 1997). The main principles were summarised by Kliebard (1986: 191, Vadeboncoeur, 1997: 19) as follows: 'The aim of Progressive Education is the freest and fullest expansion of the individual, based upon the scientific study of his physical, mental, spiritual, and social characteristics and needs.' Based on these principles, teachers had to learn to struggle between the old-fashioned, subject-centered, authoritarian traditional school and the modern, child-centered, flexible, democratic, progressive school. The Progressive Education Association was formed in 1919 with the sole purpose of applying the theories of Dewey in advancing educational reform (Pulliam and Van Pattern, 1995). Dewey's influence on American education brought fundamental changes in the way education was conceived, and there emerged new thoughts about schooling and new patterns of classroom life (Darling, 1994), with public schools extended to nearly all Americans (Lawrence, 1952).

Dewey explained the relationship between the school and society. He pointed out the necessity for 'certain differences in the methods and materials of school work that it might be better adapted to present social needs.' (Dewey, 1899) He was concerned that schools were not providing children with enough opportunities to learn what they would have learned in their home surroundings. Practical activities were important for learning rather than through words and books. Dewey emphasized the interest of children as a source for learning, the imagination as the medium in which the child lives (Dewey, 1915). In his one of the articles Dewey expressed his pedagogic creed on 'what education is':

- I believe that all education proceeds with the participation of the individual in the social consciousness of the race. This process begins unconsciously almost at birth. I believe that the only true knowledge comes through the stimulation of the child's power by the demands of the social circumstances in which he finds himself

- I believe that this institutional process has two sides-one psychological and one sociological and that either can be subordinated to the other or ignored without evil results following.

- I believe that knowledge of social positions, of the present state of civilization, is necessary in order properly to interpret the child's power.

- I believe that the emotional and social sides are naturally related and that education cannot be regarded as a settlement between the two.

- I believe that each of these doubts is true when urged against one side isolated from the other. To know what power is, we must know what its end, use, or function is, and these we cannot know to save as we conceive of the individual as active in social relationships.

In sum, I believe that the individual who is to be educated is social and that society is an organic union of individuals. If we reject the social factor from the child, we are left only with a concept; if we drop the individual element from the community, we are left only with an inert and lifeless mass. Education, therefore, must begin with a psychological perspicacity into the child's capacities, interests, and habits. It must be controlled at every point by reference to these same considerations. (1897, pp. 19-22).

Dewey (1897) believed that 'education is the fundamental method of social progress and reform,' and he maintained that for the children, education was 'a process of living and not a preparation for future living.' In this spirit, he stated the ways which should be considered while education is carried on: 
- The active side should precede the passive in the development of child nature,

- Ideas result from the action and devolve for the sake of better control of action,

- The image is the great device of instruction,

- The interests are the signs and symptoms of growing power,

- Only through the continual and sympathetic observation of childhood's interests can the grown-up enter into the child's life and see what is ready for, and upon what material it could work most readily and fruitfully,

- The emotions are the reflex of actions,

- We can only secure the right attitudes of action and thought, concerning the good, the true, and the beautiful; the emotions will, for the most part, take care of themselves. (Dewey, 1897, pp. 27-30)

Dewey (1956b) likened this new approach to education to the Copernican revolution. He states:

In traditional education, 'the center of gravity is outside the child. It is in the teacher, the textbook, anywhere and everywhere you please except in the immediate abilities and activities of the child himself... Now the change which is coming into our education is the shifting of the center of gravity. It is a change, a metamorphosis, not unlike that proposed by Copernicus when the enormous center shifted from the earth to the sun. In this case, the child becomes the sun about which the appliances of education turn; he is the center about which they are organized' (p. 34).

Dewey advocated that children pursuing their studies would be motivated to speculate, observe, gather information, and test outguesses or hypotheses to solve their problems (Dewey, 1938; Pollard and Bourne, 1994). Based on this ideal, Dewey's followers developed 'Project Method,' which focuses on the interest of the individual to find out more about something or to solve some problem. In this method, the individual becomes aware of a problem and constructs, improves, and plans solutions. Then the plan is carried, and the solution evaluated. All this is supposed to be interesting to the individual as he is all involved.
Different from Rousseau, who saw the education of a child in an ideal and isolated environment virtually with no history and social relationships (Entwistle, 1970), Dewey (1956a; 1956b) believed that schools are necessary arrangements for learning and school should not be separated from society. Instead, they should reflect on the real-life of society. He agrees with Rousseau that children are different from adults, and education should meet the needs and developmental stages of children. Still, he disagrees with him on the value of a pedagogy which just stirs up children's interests 'without directing it towards definite achievement' (Dewey, 1956a: 16). Dewey argues for a pedagogy which should 'get hold of the child's natural inclinations and instincts, and to employ them so that the child is carried on to a higher plane of perception and judgment, and equipped with more efficient habits; so that the child has an extended and deepened consciousness and increased control of powers of action' (p. 127-128). Dewey stresses that if such a result is not assigned, the play would simply be an amusement to children with no function in promoting educational growth. In other words, learning should not be simply in the form of play, but in play, which fosters reflection and understanding through scientific inquiry (Alexander, 2000). Dewey believes that children need experience and affection, as well as various activities as conditions for learning. Learning for children is a process of active thinking and problem solving (Dewey, 1956b). About the teacher's roles in child-centered education, Dewey insists that learning should be directed, and it should not be left to the child to grow out of his free will. For Dewey, the central question of education is how to take hold of the child's interests and give them direction. 'Through direction, through organized use, they tend toward valuable results, instead of scattering or being left to merely impulsive expression' (Dewey, 1956b: 36). Dewey further argues that the development of the child and the implementation of the curriculum should not be viewed as opponents to each other. He warns teachers to guard against the danger with this 'new education' to simply 'let children think things out for themselves without supplying any of the environing conditions which are requisite to start and guide thought. Nothing can be translated from 
nothing' (Dewey, 1956a: 18). For Dewey, it is the child, not the curriculum that should be at the center of the school.

The claims made by Rousseau, Froebel, and Dewey that all children follow a natural sequence of growth were further strengthened by Piaget. As a result of extensive experiments and tests, he maintained that children's cognitive development follows four biologically-based phases with each representing a different way of achieving material and rational thought (Turner, 1975; Wood, 1998). The significant implication is that the effectiveness of teaching depends on children's readiness to assimilate and accommodate new information. Until the child is ready, it is futile to try to teach. Piaget's works led to the initial formation of the constructivist theory. According to Piaget, children acquire an understanding of the world about them primarily through an analysis of their actions upon the world, not by imitation or memorization, although these factors make contributions (Piaget, 1970). In other words, every learner constructs his or her knowledge by actively making sense of the world around him/ her as opposed to receiving ideas from a teacher or an authority complete and correct. Learning is an internal and personal process largely obtained from first-hand experiences and communication with other people (Selley, 1999). Therefore, each individual is viewed as an active agent in his learning environment (Turner, 1975), and he constructs new knowledge based on what is already known (Marshall, 2000).

Although Piaget accepts that social experiences and inter-personal communication are an influential factor for children's cognitive development, they play a rather limited role in his theory as they are modified by children's readiness at a particular stage of cognitive development (Wood, 1998). In contrast to Piaget's concept of the isolated individual learner, both Vygotsky and Bruner offered a way of conceptualizing the learning process in a social context, adding an interactive dimension to practical learning. For Vygotsky, the child is not an isolated learner in a world of objects but an active discoverer or participant in a world full of other people with whom he/she interacts to gain experiences and understanding of the world around him/her(Cameron, 2001). Therefore, Vygotsky is often associated with the socio-constructivist theory (Wood, 1998; Cameron, 2001). Vygotsky (1962,1978) emphasizes interaction and engagement with learning tasks in a social context through a language based on the concept of 'Zone of Proximal Development' (ZPD). In his words, this means 'the discrepancy between a child's mental age and the level he reaches in solving problems with assistance' (Vygotsky, 1962: 103). He states that 'with assistance, every child can do more than he can by himself - though only within limits set by the state of his development.' That is to say, learning can best be accomplished through the dynamic interaction between the teacher and the learner and between learners. With the teacher's help through questions and explanations or with more capable peers' support, the learner can move to a higher level of perception with extended skills and knowledge. Through discussion with otherswhere ideas are shared, challenged, negotiated, and justified-new levels of conceptual understanding can be reached (Edwards and Mercer, 1987; Vygotsky, 1978). The implication of Vygotsky's ZPD is that the teacher plays a crucial role in helping the child in learning by providing a bridge between what is known and what is to be learned instead of leaving the child alone to figure things out for himself. Children should be given opportunities to actively compete and contribute to their learning guided by the teacher and gradually take on more responsibility for their learning (Wood, 1998). Bruner (1977), along with Vygotsky, stressed the importance of teacher's roles in children's learning and the nature of interaction in the learning environment. He coined the term 'scaffolding' to illustrate that the tasks of adults are to assist children's understanding across the zone of proximal development through carefully structured learning tasks and the use of language.

The influence of child-centered ideology on British education was, for a long time, rather limited. It became popular during the 1920s to 1930 s in infant education under the influence of the Froebel Society and Dewey's writings (The Open University, 1984a). Still, it was not until the 1960s that the philosophy of child-centredness was endorsed by official reports in Britain of which the best known are Primary Education in Scotland or the Primary Memorandum (SED, 1965) which claimed to be 
very much based on Piaget's works, and Children and their Primary Schools orThe Plowden Report (CACE, 1967), which was said to be influenced more by ideas from Rousseau, Dewey and Vygotsky. The latter contains the well-known rubric, 'At the heart of the educational process lies the child' (Para. 9). These two official documents noted above were considered landmarks in the development of childcentered education in Britain (Darling, 1994).

In the 1920s and 1930s, there were major changes in the structure of primary education in Britain, and the more didactic and syllabus-centered approach was then succeeded by an educational style that focused on a more LCT approach. The Plowden Report, which was published by the UK government in 1967, built a primary system concentrating on pedagogy and the needs of deprived children in more deprived areas, with the aim of "producing a creative, autonomous, yet responsible and moral young citizenry across the nation" (pp. 40-41). This report focused intensively on more informal, flexible teaching methods, and group work. The Plowden Report made learnercentered approaches widespread in the UK in the 1960s, and these approaches to teaching and learning now dominate in the UK and most of the Western world (O'Sullivan, 2004). Learner-centered approaches are also endorsed and promoted in many developing countries. (Altinyelken, 2011; Black, Govinda, Kiragu, \& Devini, 1993; Lall, 2010) Plowden's report on children and their primary school in Britain is considered one of the most remarkable reports on the theme. 'At the heart of, the instructional process lies the child' is the most quoted passage from this report, which embraces the basic principle of the LCT. The report emphasized that policy, material, or other things were to be in harmony with the nature of the child and acceptable to him if the desired effects are to be achieved. The proposal was on more informal and flexible teaching techniques such as project work. The school was supposed to provide the right environment for children, allow them to be themselves and develop in the way and pace appropriate to them. The important ideologies of Plowden report endorse all teaching in the primary schools to be sensitive to child's innate development; the curriculum to be open and thematic; and facilitation of learning through providing resources, questioning and supporting rather than teaching in more direct or didactic ways (Doddington and Hilton, 2007). The following extracts from both the Primary Memorandum (SED, 1965) and the Plowden Report (CACE, 1967), can be said to capture most of the elements in child-centered education:

At the heart of the instructional process lies the child. No advances in policy, no acq.uisition of new devices have their desired effect unless they are in harmony with the nature of the child unless they are fundamentally adequate to him (CACE, 1967: Para. 9)

These individual variations must be recognized and catered for in all spheres of the child's activities in school. The teacher's methods and organization should be sufficiently flexible to allow each child to progress at an appropriate pace and to achieve satisfaction and success at his level (SED, 1965: 4)

(a) Individual differences between children of the same age are so prominent that any class, however, comparable it seems, must always be treated as a body of babies needing an individual and different application. (b) Until a child is ready to take a careful step forward, it is a waste of time to try to prepare him to take it (CACE, 1967: Para. 75).

It is now understood that learning occurs most effectively when the learner is personally involved in a purposeful activity that captures his interest or arises from it. Consequently, the emphasis in primary education is now more on learning by the pupil than on instruction by the teacher (SED, 1965: 60)

Finding out' has proved to be better for children than being told (CACE, 1967: Para. 1233).

Emotional, social, and intellectual aspects are closely weaved in mental growth: the child is a total personality. Sentient life provides the spur and, in many ways, gives meaning to experience (CACE, 1967: Para. 65).

The curriculum is not to be conceived of as several discrete subjects, each requiring a specific allocation of time each week or each 
month. Indeed, it is quite impossible to treat the subjects of the curriculum in isolation from one another if education is to be meaningful to the child (SED, 1965: 37)

As we can see from the above, basic principles advocated include the ideas that education should be compatible to children's nature and their natural pace of development; teaching should be individualized to meet children's differences; teaching and learning should provide a wide range of experiences for children to learn actively and creatively through play and discovery method; the curriculum should be integrated; every child should be cared for and respected, etc. All these reflect almost all the historical meanings of child-centredness and have instigated some fundamental changes in the way education was perceived and conducted before the 1960s with children seated at their desks and treated as the passive recipients of knowledge provided by teachers (Darling, 1994). Also, 'the idea of education which caters to each child's interests suggests designing a curriculum which allows choices between different activities to the child's actual preferences' (Darling, 1986: 37).

Embracing learner-centered approach Kilpatrick (Kilpatrick, 1918; Pollard and Bourne, 1994) developed four-stage learning from the real situation through topics: The children specify what they want to know, ask questions, and devise ways of finding out; They consult books and develop an action plan; They execute that work; They present findings to others, review, and make judgments. It has also been advanced that if it is not children's experiences and interests that direct the curriculum content, then their activities and interests need to be considered by the teacher. This is termed as a 'child-considered pedagogy' (Collins, Insley, and Soler, 2001). Childconsidered pedagogy takes account of children's experiences and interests, but the determination is made by the teacher.

LCT, as emphasized in the aims of the primary education system in Nepal, has been reiterated in major educational documents. Concept paper for 'Further Support on Basic and Primary Education in Nepal 2004 - 2009' emphasizes:
The qualities of classroom learning experiences need to develop, further, away from treating the students in classes as homogeneous units, and away from rote learning. The focus of teaching-learning methodology will be on learner-centered active learning with teachers being aware of each student's level at all times through using a wide range of formal and informal techniques. (MOES, 2002, p. 13).

The above statement has been carried on to the core document of 'Education for All 2004-2009' (MOES, 2003).

LCT approach requires tailoring pedagogical processes around the need, interests, learning styles, background, etc. of the child. Wiles and Bondi (1993) viewed that a child-centered approach needs to focus on the individual student to provide learning experiences in the affective, cognitive, and psychomotor areas. 'LCT embraces principles of quality and equity in education. Such a list is provided in the manual-'primary curriculum development in Nepal' developed for curriculum developers by Opifer Ltd (June 2002). These are as following:

- All children are equal and should be treated with love and respect.

- Put children first, respond to their needs and build on their knowledge.

- Children are unique individuals with different needs, interests, and abilities.

- Children come to school already knowing many things.

- Children learn at different rates, i.e., they have their own pace.

- Children are curious and inquisitive.

- Children learn best through concrete, hands-on experiences.

- The learning environment should stimulate children's development.

- Different children learn in different ways, and varieties of strategies are necessary to cater to the needs and interests of individual children.

The following table, based on Bell (1981: 17), The Open University (1984b: 31), and Bennett (1976: 38), illustrates the main characteristics of the LCT versus the traditional approaches to education. 
Table 1: Features of Learner-Centered Teaching and Traditional Teaching

\begin{tabular}{|c|c|c|}
\hline $\begin{array}{l}\text { S. } \\
\text { No. }\end{array}$ & $\begin{array}{c}\text { Learner Centered } \\
\text { Teaching }\end{array}$ & $\begin{array}{c}\text { Traditional } \\
\text { Teaching }\end{array}$ \\
\hline 1 & $\begin{array}{l}\text { Emphasises interest and } \\
\text { play }\end{array}$ & $\begin{array}{l}\text { Emphasises } \\
\text { knowledge and work }\end{array}$ \\
\hline 2 & $\begin{array}{l}\text { Emphasises learning by } \\
\text { discovery }\end{array}$ & $\begin{array}{l}\text { Emphasises direct } \\
\text { teaching }\end{array}$ \\
\hline 3 & $\begin{array}{l}\text { Emphasises pupil active } \\
\text { roles }\end{array}$ & $\begin{array}{l}\text { Accept pupil passive } \\
\text { roles }\end{array}$ \\
\hline 4 & $\begin{array}{l}\text { Emphasises creative } \\
\text { expressions }\end{array}$ & $\begin{array}{l}\text { Emphasises factual } \\
\text { learning }\end{array}$ \\
\hline 5 & Integrated subject matter & $\begin{array}{l}\text { Separate subject } \\
\text { matter }\end{array}$ \\
\hline 6 & $\begin{array}{l}\text { Rejects rigid forms of } \\
\text { control }\end{array}$ & $\begin{array}{l}\text { Emphasises overt } \\
\text { control }\end{array}$ \\
\hline 7 & $\begin{array}{l}\text { Emphasises intrinsic } \\
\text { motivation more than } \\
\text { external rewards }\end{array}$ & $\begin{array}{l}\text { Depends much on } \\
\text { external rewards }\end{array}$ \\
\hline 8 & $\begin{array}{l}\text { Pupils participate in } \\
\text { decision-making in the } \\
\text { process of learning }\end{array}$ & $\begin{array}{l}\text { Decision-making } \\
\text { is firmly in the } \\
\text { teacher's hands. }\end{array}$ \\
\hline 9 & $\begin{array}{l}\text { Pupils work } \\
\text { cooperatively }\end{array}$ & $\begin{array}{l}\text { Pupils work in } \\
\text { competition with } \\
\text { each other }\end{array}$ \\
\hline 10 & There is little testing used & $\begin{array}{l}\text { Regular testing is } \\
\text { used }\end{array}$ \\
\hline 11 & $\begin{array}{l}\text { Emphasises that all } \\
\text { children are equal and } \\
\text { teacher respects each } \\
\text { individual }\end{array}$ & $\begin{array}{l}\text { Favours only the } \\
\text { able children and } \\
\text { believes in strict } \\
\text { streaming }\end{array}$ \\
\hline 12 & $\begin{array}{l}\text { Uses open plan } \\
\text { classrooms with no rigid } \\
\text { physical boundaries } \\
\text { dividing one learning } \\
\text { group from another }\end{array}$ & $\begin{array}{l}\text { Uses separate, } \\
\text { enclosed rooms } \\
\text { for each class and } \\
\text { teacher }\end{array}$ \\
\hline 13 & $\begin{array}{l}\text { Teacher as guide to } \\
\text { educational experiences } \\
\text { of the children }\end{array}$ & $\begin{array}{l}\text { Teacher as } \\
\text { distributor of } \\
\text { knowledge }\end{array}$ \\
\hline
\end{tabular}

Based on Bell (1981: 17, Open University, 1984b: 31) and Bennett (1976: 38)

\section{Conclusion}

A thorough review of the research shows that LCT has been developing for over five thousand years, and it continues to take on various shapes. Yet, many of the inclinations that are placed in this education model tend to proceed. The nature of all philosophy is to guide thinking; therefore, LCT should guide teachers' thoughts, which will inevitably shape their behavior. Because the nature of all experience is fluid and temporary, responsible use of this model requires educators to commit to a life-long chase of improving their understanding of LCT and of the broader processes called teaching and learning. The changing demographics of the student society and the more consumer/client-centred culture in today's society have produced a climate where the use of LCT is thriving. The interpretation of the term LCT appears to vary between authors as some equate it with 'active learning.'

In contrast, others take a more comprehensive definition, including active learning, choice in learning, and the shift of power in the teacher-student relationship. It is you, used very commonly in the literature, but this has not necessarily transferred into practice. LCT is not without some criticism, but in general, it has been seen to be a positive experience. For example, Altinyelken (2011). emphasizes the value of LCT: 'Placing learners at the heart of the learning process and meeting their needs, is taken to a growing step in which LCTmean that persons can learn what is appropriate for them in suitable ways. Waste in human and enriching resources is reduced as it suggested learners no longer have to learn what they already know or can do, nor what they are impassive in'. Although understanding that it is not necessarily an easy task, it is hoped that this article has gone some way to providing evidence and ideas to move you higher up the continuum towards a more LCT practice.

\section{References}

Alexander, R. Culture and Pedagogy: International Comparisons in Primary Education. Blackwell Publishers Ltd, Oxford, 2000.

Altinyelken, H. K. "Student-Centred Pedagogy in Turkey: Conceptualisations, Interpretations and Practices." Journal of Education Policy, vol. 26, no. 2, 2011, pp. 137-160.

Attard, A. et al. "Student-Centred Learning: An Insight into Theory and Practice." Time for a New Paradigm in Education: Student Centered Learning, edited by A. Attard, Partos Timisoara, 2010. 
Bell, B. Contemporary Issues in Education. Milton Open University Press, 1991.

Bennett, S. N. Teaching Styles and Pupil Progress. Open Books, London, 1976.

Black, H. et al. School Improvement in the Developing World. An Evaluation of the Aga Khan Foundation Programme. ODA Research Evaluation Report, 1993.

Blumberg, P. Developing Learner-Centered Teaching: A Practical Guide for Faculty. Jossey-Bass, San Francisco, 2008.

Brodiea, K., Lelliotta, A., and Davis, H. "Forms and Substance in Learner-Centred Teaching: Teachers' Take-up from an In-Service Programme in South Africa." Teaching and Teacher Education, vol. 18, no. 5, 2002, pp. 541-559.

Cameron, L. Teaching Languages to Young Learners. Cambridge University Press, 2001.

Campbell, J.K. The Children's Crusader. Teachers College Press, 1967.

Chung, S., and Walsh, D. J. "Unpacking ChildCentredness: A History of Meanings." Journal of Curriculum Studies, vol. 32, no. 2, 2000, pp. 215-234.

Darling, J. Child-Centred Education and its Critics. Paul Chapman Publishing, London, 1994.

Darling, J. "Child-Centred, Gender-Centred: A Criticism of Progressive Curriculum Theory from Rousseau to Plowden." Oxford Review of Education, vol. 12, no. 1, 1986, pp. 31-40.

Dewey, J. The School and Society. The University of Chicago Press, Chicago, 1899, pp. 30-50.

Dewey, J. "Froebel's Educational Principles." The School and Society. Cosmo Publications, New Delhi, 1915, pp. 95-107.

Dewey, J. "My Pedagogic Creed." School Journal, vol. 54 , no. 3 , 1897, pp. 77-80.

Dewey, J. Experience and Interaction. Macmillan, New York, 1938.

Dewey, J. The Child and the Curriculum. University of Chicago Press.

Dewey, J. School and Society. University of Chicago Press.

Doddington, C., and Hilton, M. Child-Centred Education: Reviving the Creative Tradition. Sage, 2007.
Dupin-Bryant, P. A. "Teaching Styles of Interactive Television Instructors: A Descriptive Study." The American Journal of Distance Education, vol. 18, no. 1, 2004, pp. 39-50.

Entwistle, H. Child-Centred Education. Routledge, London, 2012.

Freire, P. Pedagogy of the Oppressed. Penguin, London, 1996.

Froebel, F. The Education of Man. A. Lovell \& Company, New York, 1885.

Garforth, F. W. John Locke: Some thoughts Concerning Education. Barron's Educational Series, Inc, 1964.

Gauthier, C., and Dembele, M. "Quality of Teaching and Quality of Education: A Review of Research Findings." Education for All Global Monitoring Report, UNESCO, Paris, 2004.

Green, J. A. Pestalozzi's Educational Writings. Edward Arnold, London, 1912.

Green, J.A. Educational Ideas of Pestalozzi. W. B. Clive. University Tutorial Press, London, 1907.

Harmelen, U. "Is Learner Centred Education, Child Centred?." Journal for Educational Reform in Namibia, vol. 8, no. 1, 1998, pp. 1-10.

Heafford M. R. Pestalozzi: His thought and its Relevance Today. Methuen \& Co Ltd, London, 1967.

Henson, T. K. "Foundations for Learner-Centered Education: A Knowledge Base." Education, vol. 124, no. 1, 2003, pp. 5-16.

Kliebard, H. M. The Struggle for the American Curriculum, 1893-1958. Routledge, New York, 1986.

Lall, M. Child centred learning and teaching approaches in Myanmar. 2010.

Lambert, N. M. and McCombs, B. L. "Introduction: Learner-Centred Schools and Classrooms as a Direction for School Reform." How Students Learn: Reforming Schools through Learnercentred Education, edited by N.M. Lambert and B.L. McCombs. American Psychological Association, 1997, pp. 1-22.

Lawrence, E. Friedrich Froebel and English Education. Routledge and Kegan Paul, London, 1952. 
Lea, S. et al. 'Higher Education Students' Attitudes to Student-Centred Learning: Beyond Educational Bulimia?." Studies in Higher Education, vol. 28, no. 3, 2003, pp. 321-334.

Lilley, I. Friedrich Froebel: A Selection from his Writings. Cambridge University Press, Cambridge, 1967.

Marshall, H. H. "Teaching Educational Psychology: Learner-Centered and Constructivist Perspective. How Students Learn: Reforming Schools through Learner-Centred Education, edited by N. M. Lambert and B. L McCombs. American Psychological Association, Washington DC, 2000, pp. 449- 461.

Muzumara, P.M. Teacher Competencies for Improved Teaching and Learning. Bhuta Publishers, Lusaka, 2011.

Mtika, P., and Gates, P. "Developing LearnerCentred Education Among Secondary Trainee Teachers in Malawi: The Dilemma of Appropriation and Application." International Journal of Educational Development, vol. 30, no. 4, 2010, pp. 396-404.

Ozmon, H. A., and Craver, S.M. Philosophical Foundations of Education, Prentice Hall, Upper Saddle River, N.J., 1999.

O'Neill, G., and McMahon, T. "Student-Centred Learning: What does it mean for Students and Lecturers?." Emerging Issues in the Practice of University Learning and Teaching, edited by G. O’Neill, et al. AISHE, 2005, pp. 27-36.

O'Sullivan, M. “The Reconceptualisation of LearnerCentred Approaches: A Namibian Case Study." International Journal of Educational Development, vol. 24, no. 6, 2004, pp. 585-602.

Perkinson, H. J. Since Socrates: Studies in the History of Western Educational Thought. Longman Inc, New York, 1980.

Pestalozzi, J. H. How Gertrude Teaches her Children: An Attempt to Help Mothers to Teach their Own Children, translated by L. E. Holland and F. C. Turner, 1904.

Piaget, J. "Piaget's Theory." Carmichael's Manual of Child Psychology, edited by P. Mussen, John Wiley, New York, 1970.
Pollard, A. et al. Changing English Primary Schools: The Impact of the Education Reform Act at Key Stage One. Cassell, London, 1994.

Pulliam, J.D. and Van Patten, J. The History of education in America (6th Edition), PrenticeHall, NJ, 1995.

Ravitch, D. The Troubled Crusade: American Education 1945-80. Basic Books, New York, 1983.

Schweisfurth, M. "Learner-Centred Education in International Perspective." Journal of International and Comparative Education, vol. 2, no. 1, 2013, pp. 1-8.

Selley, N. The Art of Constructivist Teaching in the Primary School: A Guide for Students and Teachers. David Fulton Publishers Ltd, London, 1999.

Simon, B. "Why no Pedagogy in England?." Learners and Pedagogy, edited by Leach, J. and Moon, B. Sage Publications, London, 1999.

Sparrows, L. Student Centred Learning. Perth Curtin University of Technology, 2000.

Sutherland, M. Theory of Education-the Effective Teacher Series. Longman, London, 1988.

Tabulawa, R. "International Aid Agencies, Learner-Centred Pedagogy and Political Democratisation: A Critique." Comparative Education, vol. 39, no. 1, 2003, pp. 7-26.

Turner, J. Cognitive Development. Methuen \& Co Ltd, London, 1975.

Vadeboncoeur, J. A. "Child Development and the Purpose of Education: A Historical Context for Constructivism in Teacher Education." Constructivist Teacher Education: Building A World of New Understandings, edited by V. Richardson, Falmer Press, London, 1997, pp. 15-37.

Vygotsky, L. S. Mind in Society: The Development of Higher Psychological Processes. Harvard University Press, Cambridge, 1978.

Vygotsky, L.S. Thought and Language. The M. I. T. Press, Cambridge, 1962.

Weimer, M. Learner-Centred Teaching: Five Key Changes to Practice. Jossey Bass, San Francisco, 2002. 
Wiles, J. and Bondi, J. Curriculum Development: A Guide to Practice. Macmillan Publishing Company, New York. 1993, pp. 110.

Windschitl, M. "Framing Constructivism in Practice as the Negotiation of Dilemmas: An Analysis of the Conceptual, Pedagogical, Cultural, and Political Challenges Facing Teachers."
Review of Educational Research, vol. 72, no. 2, 2002, pp. 131-75.

Wood, E. "Reconceptualisation Child-Centred Education: Contemporary Directions in Policy, Theory and Practice in Early Childhood." FORUM, vol. 49, no. 1, 2007, pp. 119-133.

\section{Author Details}

Dr. Rajendra Kumar Shah, Associate Professor, Tribhuvan University (Sanothimi Campus), Bhaktapur, Nepal, Email ID:drrajendrakumarshah@gmail.com. 